THE PROPERTIES OF POWDERS. PART III.

THE POWDERING OF MINERALS BY DECREPITATION.

\author{
By T. Martin Lowry, D.Sc., F.R.S., and L. P. McHatton, A.R.C.Sc. \\ (A Paper read before The Faraday Society, Monday, June 26, r922, \\ Professor Alfred W. Porter, F.R.S., President, in the Chair.)
}

Received March 16, 1922.

\title{
The Decrepitation of Barytes.
}

The phenomenon of decrepitation, whereby crystals are broken up by heat, sometimes with almost explosive violence, is familiar to all chemists in the case of lead nitrate and common salt. Amongst minerals the phenomenon is especially conspicuous in the case of barytes, where it has been utilised as the basis of an industrial method of separating barytes and blende, two minerals whose densities $\left(4^{\circ} 48\right.$ and $\left.4^{\circ} \circ 6\right)$ are so near together that they cannot readily be separated by water-washing or jigging. ${ }^{1}$

Bryant states that of twenty ores that were tested, there was only one which could not be separated by this process since the barytes refused to decrepitate and fall to powder. Our own experiments on samples of

1(i) Richards (Ore Dressing, I908, Vol. II., p. 1565) describes experiments by Raymond, at the mine of the Americus $Z$ inc and Lead Mining \& Milling Co., Missouri, where barytes was separated from blende by roasting a charge of about rooo $1 \mathrm{~b}$. on a hearth $6 \mathrm{ft}$. square for ro minutes, and then raking out into a brick cooling-floor. The mechanical analysis of the decrepitated ore was as follows :-

$>$ I2 mesh 75 per cent. ; 12/20 mesh 20 per cent. ; $<20$ mesh 5 per cent.

(ii) C. Ratel (Preparation Mécanique des Minerals, 1908,) states that at Malines blende containing barytes was decrepitated in a reverberatory furnace, at $150^{\circ}$ to $200^{\circ}$ at the rate of $\mathrm{r} 2$ tons per hour, with a consumption of 400 kilos. of coal, and at a cost of about $4^{\circ} 5^{\circ} \mathrm{fr}$. per ton; by screening through a sieve with an aperture of $0^{\circ} \mathrm{r}$ $\mathrm{mm}$. the blende was raised from 20 to 44 per cent. $Z \mathrm{n}$, whilst the barytes fraction containing Io to 12 per cent. $Z$ n represented a loss of 25 to 30 per cent.

(iii) The Engineering and Mining Foumal (New York), May Ir, Igr2, describes the Bryant apparatus, in which decrepitation was carried out in an inclined tube $12 \mathrm{ft}$. long and $\mathrm{r} 8$ ins. in diameter heated in a brick furnace built for burning oil. $\mathrm{A}_{40}$ mesh sieve retained 90 per cent. of the zinc produced at the Tahoma mine, whilst 90 per cent. of the barytes would pass a 200-mesh sieve, on which the residue of zinc is retained. The clean barytes was washed and its value was sufficient to cover the cost of the separation.

(iv) In the Engineering and Mining Fournal of June I5, Igr2, H. E. Wood of the Ore Testing Co., Denver, describes the decrepitation of barytes in a revolving pipe $6 \mathrm{ft}$. long and 6 ins. in diameter, inclined at an angle of $30^{\circ}$ and heated in the centre over a blacksmith's forge. Jig products from ro mesh to $\frac{1}{2}$ in. were fed into the upper end of the pipe and separated on a 30-mesh screen forming an extension at the lower end of the pipe.

(v) In this country the separation of barytes from galena and blende by decrepitation has been carried out by the St. Asaph Zinc, Lead and Barytes Co. and covered by patent. 


\section{THE POWDERING OF MINERALS BY DECREPITATION 83}

barytes obtained from various mines in Great Britain have shown that whilst the barytes from Cumberland, Westmorland, Yorkshire, Durham, Shropshire and the Welsh Borders decrepitated readily, no decrepitation could be effected in the case of Derbyshire barytes; and in the case of Devonshire barytes only about 40 per cent. broke down on heating. These differences correspond closely with differences in the character of the mineral; thus the marble-like varieties of barytes nearly all decrepitate well, whilst the Derbyshire barytes, which does not decrepitate at all, is relatively soft and earthy in texture.

Decrepitation can be used to separate barytes from blende, galena, pyrites and quartz, as well as from country rock. Thus it is often possible, not only to separate the barytes from the metal-bearing ores, but also to eliminate more or less completely the layers of ferric oxide and silica, which give rise to colour, and to hardness in grinding, respectively. If, however, the mineral is badly contaminated with silica, so as to render it hard and flint-like, it can as a rule no longer be decrepitated; and soft layers of ferric oxide are liable to break up on decrepitation and to pass through the sieve with the barytes.

The separation can be carried out most efficiently by using material which has already been graded by sieving. After decrepitation the mineral is regraded on sieves which are slightly finer than those which retained the mineral before decrepitation. Jig-products are particularly well adapted for this process, since the grains are uniform in size and very well cleaned. It is, however, also possible to use much finer products, e.g. a sample of barytes, which had been separated by washing on a vibrating table, gave on sieving a fraction which passed through an 80-mesh sieve but was retained by a Ioo-mesh sieve; after decrepitation this gave two fractions of approximately equal weight, one of which was retained, whilst the other passed through a i 20 -mesh sieve.

The principal risk of contamination in a decrepitated product arises from the mechanical disintegration of the other constituents; it is therefore advantageous to pass the decrepitated barytes through the finest sieve that will transmit the bulk of the product. One great advantage of the use of jigged products is that the agitation and rubbing to which these are subjected in the jigs reduce this risk to a minimum.

\section{Relationship between Decrepitation and Water-content of Barytes.}

The fineness of the powder produced by decrepitating barytes varies greatly according to the source of the mineral; thus the mineral from the Tahoma Mine (see footnote p. 82) gave a powder of which 90 per cent. would pass through a 200-mesh sieve, whilst in the case of the Missouri mineral only 5 per cent. would pass through a 20-mesh sieve. Similar variations were found in barytes from various British mines; but our interest in this aspect of the phenomenon was increased very greatly by the discovery in a sample of Lunehead barytes of a clear fragment which had resisted decrepitation in two successive experiments. The behaviour of this fragment suggested that the property of decrepitation was not inherent in the mineral, but might be due to some secondary characteristic, which was not universally present. In particular, it appeared that just as the presence of moisture affords an obvious explanation of the decrepitation of lead nitrate so conversely a perfectly transparent crystal of barytes might perhaps refuse to decrepitate because it was entirely free from included 


\section{THE POWDERING OF MINERALS BY DECREPITATION}

water. $^{1}$ A series of experiments was therefore made, in order to determine if possible the relationship between the loss in weight and the fineness of the powder produced by decrepitation of the mineral (already dried at $100^{\circ}$ ) at about $300^{\circ}$. The results obtained may be shown in tabular form as follows :-

TABLE I.

Water-Content and Decrepitation OF Barytes.

\begin{tabular}{|c|c|c|c|c|c|}
\hline \multirow{2}{*}{ Origin of Mineral. } & \multirow{2}{*}{$\begin{array}{c}\text { Percentage } \\
\text { Loss of } \\
\text { Weight. }\end{array}$} & \multicolumn{4}{|c|}{ Fineness of Powder after Decrepitation. } \\
\hline & & & $30 / 60$. & $60 / \times 20$. & I 20 \\
\hline $\begin{array}{l}\text { Long Fell, Westmorland } \\
\text { Bulthy, Montgomeryshire } \\
\text { Gatton, Shropshire } \\
\text { Snailbeach, Shropshire } \\
\text { Lunehead, Yorkshire . } \\
\text { Braithwaite, Cumberland } \\
\text {,, ", }\end{array}$ & $\begin{array}{l}0.04 \\
0.12 \\
0.12 \\
0 \cdot 13 \\
0.21 \\
0.45 \\
0.51\end{array}$ & $\begin{array}{c}\text { Per cent. } \\
86 \\
17 \\
8 \\
\text { 10 } \\
9 \\
6 \\
5\end{array}$ & $\begin{array}{c}\text { Per cent. } \\
\text { 14 } \\
57 \\
47 \\
48 \\
22 \\
30 \\
32\end{array}$ & $\begin{array}{c}\text { trace } \\
\text { I8 } \\
28 \\
26 \\
33 \\
30 \\
35\end{array}$ & $\begin{array}{r}-8 \\
17 \\
16 \\
36 \\
32 \\
28\end{array}$ \\
\hline
\end{tabular}

From these experiments it appears that there is a close relationship between the amount of water included in the mineral and the fineness of the powder produced from it by decrepitation. In particular, a single clear crystal of Long Fell barytes, which lost only 0.04 per cent. of moisture when heated, broke down for the most part into little rhombic prisms having an edge of about $2 \mathrm{~mm}$., and somewhat similar in size and appearance to the small fragment of Lunehead barytes which had survived two decrepitations. At the other end of the scale, samples containing 0.2 per cent. or more of moisture broke down to a fine powder, containing on the average over 32 per cent. of particles small enough to pass through a I20-mesh sieve, whilst the proportion retained on a 30-mesh sieve was always less than ro per cent.

\section{Decrepitation of Other Minerals.}

Decrepitation is also known to occur in a certain number of other minerals, including celestine, $\mathrm{SrSO}_{4}$, and crocoite, $\mathrm{PbCrO}_{4}$, two minerals of similar composition to barytes and, in the case of celestine, actually isomorphous with it. Quantitative decrepitation on the same lines as in the case of barytes gave the results shown in Table II.

It will be observed that in the case of celestine the coloured sample, which contained a two-fold proportion of moisture, broke down much more completely than the clear colourless crystals, which resisted decrepitation even more effectively than a clear crystal of barytes of equal water-content. On the other hand, crocoite containing over $0 \% 4$ per cent. of moisture, corresponding with wettest samples of barytes, gave a very similar product, leaving only 17 per cent. on a 30 -mesh sieve and giving 24 per cent. of fine powder passing through I $20-$ mesh.

${ }^{1}$ Gmelin (Tr. H. Watts, $1848, I, I_{4}$ ) attributes decrepitation in water-soluble salts to enclosed "water of decrepitation". In the case of minerals, where it cccurs. irregularly, he attributes it to enclosed gases (compare H. Rose, Pogg. Ann., 48, 354). In our experiments water was obviously liberated, but was estimated only by loss of weight. 
THE POWDERING OF MINERALS BY DECREPITATION 85

TABLE II.

Water-Content and Decrepitation of Other Minerals.

\begin{tabular}{|c|c|c|c|c|c|c|}
\hline \multirow{2}{*}{\multicolumn{2}{|c|}{ Mineral. }} & \multirow{2}{*}{ Moisture. } & \multicolumn{4}{|c|}{ Fineness of Powder after Decrepitation. } \\
\hline & & & $>_{30}$ & $30 / 60$. & $60 / 120$. & $<\mathrm{r} 20$. \\
\hline $\begin{array}{l}\text { Celestine } \\
\text { Celestine } \\
\text { Celestine } \\
\text { (coloured sample) } \\
\text { Crocoite }\end{array}$ & . & $\begin{array}{l}\text { Per cent. } \\
0.048 \\
0.035 \\
0.09 \\
0.44\end{array}$ & $\begin{array}{l}98 \cdot 5 \\
94 \\
68 \\
17\end{array}$ & $\begin{array}{c}\mathbf{I} \cdot 2 \\
5 \\
26 \\
25\end{array}$ & $\begin{array}{l}\operatorname{trace} \\
\mathrm{I} \\
34\end{array}$ & $\begin{array}{l}0.5 \\
24\end{array}$ \\
\hline
\end{tabular}

\section{Decrepitation of Sodium Chloride.}

Four experiments were made using (i) a clear colourless crystal of rock salt about $20 \mathrm{~mm}$. in diameter; (ii) a lump of common brown rock salt ; (iii) a sample of pure crystallised sodium chloride, dried at $100^{\circ}$; (iv) a sample of coarse freezing salt, which had been dried in a steam oven at $100^{\circ}$ during one hour, and separated from small particles on a 30 -mesh sieve. The results of the experiments are set out in Table III.

TABLE III.

Decrepitation of Sodium Chloride.

\begin{tabular}{|c|c|c|c|c|c|}
\hline \multirow{2}{*}{ Nature of Sample. } & \multirow{2}{*}{$\begin{array}{l}\text { Loss of } \\
\text { Weight on } \\
\text { Heating. }\end{array}$} & \multicolumn{4}{|c|}{ Fineness after Decrepitation. } \\
\hline & & & $30 / 60$. & $60 / 120$ & \\
\hline $\begin{array}{l}\text { Colourless crystal } \\
\text { Brown rock-salt } \\
\text { Pure sodium chloride } \\
\text { Freezing salt }\end{array}$ & $\begin{array}{l}\text { Per cent. } \\
0^{*} 08 \\
0^{\circ} 4 \\
0^{*} 6 \\
5^{\circ} 5\end{array}$ & $\begin{array}{l}99 * 4 \\
96 \cdot 6 \\
9 x \cdot 3 \\
55 \cdot 6\end{array}$ & $\begin{array}{r}0^{\circ} 4 \\
2^{\circ} 0 \\
5^{\circ} 0 \\
24^{\circ} 2\end{array}$ & $\begin{array}{l}0 \cdot 2 \\
0 \cdot 6 \\
3 \cdot 7 \\
8 \cdot 2\end{array}$ & $\overline{0.8}$ \\
\hline
\end{tabular}

It will be seen that the colourless crystal was almost free from in. cluded moisture, and that when heated it decrepitated to so slight an extent that only 0.6 per cent. of the product passed through a 30-mesh sieve ; the remainder consisted of clear cleavage-fragments, the largest of which was $15 \times 12 \times 8 \mathrm{~mm}$. and completely resistant to heat. The coloured rock salt contained about 0.4 per cent. of moisture, but decrepitated to only about the same extent as celestine containing 0.04 per cent., the actual figures for the sieving test agreeing very closely with the average of the two samples of celestine for which data are given in Table II. This sample contained a fair amount of broken material, but also several clear colourless cleavage-fragments, the largest of which was $\mathrm{r} 2 \times 4 \times 3 \mathrm{~mm}$. The pure sodium chloride decrepitated only slightly, but the freezing salt, which lost over 5 per cent. of its weight on heating, decrepitated much more thoroughly (although to a far lesser degree than most of the samples of barytes) and gave a considerable proportion of powder passing through 30,60 and I20-mesh. In this case, therefore, there appears to be again a definite correspondence between the water-content of the crystals and the fineness of the powder produced by decrepitation. 


\section{THE POWDERING OF MINERALS BY DECREPITATION}

\section{Summary.}

I. The decrepitation by heat of barytes from various sources is described, together with its technical application in the separation of barytes from other minerals.

2. The decrepitation of barytes may be attributed, as in the case of water-soluble salts such as lead nitrate, to the presence of included water; clear fragments have been obtained which are completely resistant to decrepitation by heat and a semi-quantitative relationship has been found between the water-content of barytes and the fineness of the powder produced by decrepitation.

3. Quantitative experiments are also described on the relationship between the loss of weight and the fineness of the powder produced by the decrepitation of celestine, crocoite and common salt.

During the later stages of this work, assistance was received from the Department of Scientific and Industrial Research, to which we desire to express our indebtedness.

\section{University Chemical Laboratory, Cambridge.}

